\title{
Impacts of Climate Change and Human Activities on Runoff and Sediment Load of the Xiliugou Basin in the Upper Yellow River
}

\author{
Haifang Yao, ${ }^{1,2}$ Changxing Shi, ${ }^{1}$ Wenwei Shao, ${ }^{1,2}$ Jianbin Bai, ${ }^{1,2}$ and Hui Yang ${ }^{1,2}$ \\ ${ }^{1}$ Institute of Geographic Sciences and Natural Resources Research, Key Laboratory of Water Cycle and Related Land Surface Processes, \\ Chinese Academy of Science, Beijing 100101, China \\ ${ }^{2}$ University of Chinese Academy of Sciences, Beijing 100049, China
}

Correspondence should be addressed to Changxing Shi; shicx@igsnrr.ac.cn

Received 27 January 2015; Accepted 11 April 2015

Academic Editor: Steffen Mischke

Copyright (C) 2015 Haifang Yao et al. This is an open access article distributed under the Creative Commons Attribution License, which permits unrestricted use, distribution, and reproduction in any medium, provided the original work is properly cited.

\begin{abstract}
Using data of temperature, wind, precipitation, water discharge, and sediment load, the changes in runoff and sediment load of the Xiliugou basin in the upper Yellow River were investigated and the contributions of climate change and human activities to these changes were quantitatively estimated. Results show that the runoff and sediment load of the stream declined gradually in 1960-2012. According to the abrupt change point detected, the runoff and sediment series were divided into two periods: 1960-1998 and 1999-2012. The reductions of runoff and sediment load in 1999-2012 were found to be related to climate change and human activities, and the latter played a dominant role with a contribution of about $68 \%$ and $75 \%$, respectively. The effects of rainfall intensity should be considered to avoid overestimating or underestimating the contributions of rainfall changes to the variations of runoff and sediment load in the semiarid region. An inspection of changes in water discharge and sediment regime indicated that the frequency of discharge between 0 and $5 \mathrm{~m}^{3} / \mathrm{s}$ increased while that between 5 and $1000 \mathrm{~m}^{3} / \mathrm{s}$ decreased in 2006-2012. This phenomenon can be attributed principally to the soil and water conservation practices.
\end{abstract}

\section{Introduction}

Warming of the climate system is unequivocal. According to the IPCC [1], the average global surface temperature increased by $0.85^{\circ} \mathrm{C}$ over the period $1880-2012$. With global warming and temperature increasing, the rainfall will be affected, hence river flows [2]. Water discharge and sediment flux, which are the two most important elements of the hydrologic cycle, not only reflect the characteristics of river systems themselves but also reflect the changing of the catchment environment $[3,4]$. Therefore, the impacts of climate change on the streamflow [2-13] and sediment [3, 4, 9-15] have been well studied in the literature.

Aside from climate change, recently, human activities (such as land use/land cover change [16-24], dam construction and operation of large reservoirs $[10,12,25,26]$, and soil and water conservations $[4,12,27])$ have played a crucial role in the changes of water discharge and sediment flux. The study by Walling [28] analyzed the changes of sediment yield of the Black Sea over the past 20,000 years, revealing that climate change was more important than human impact in driving changes in sediment yield in the long time scale. The same study summarized the trends of runoff and sediment loads for the Yellow River in China, Chao Phraya River in Thailand, and the Kolyma River in Eastern Siberia and concluded that human activities were primary drivers causing changes in the sediment loads of the world's rivers in the short time scale. For the runoff variation, Miao et al. [29] suggested that climate change usually impacts it periodically and lastingly, whereas human activities impact it suddenly and directionally.

Climate change often interacts with anthropogenic impacts in causing runoff and sediment load changes, and defining their contributions is of significance for managing rivers. Some recent studies have come to quantify the relative effects of climate change and human activities on streamflow and sediment load. Naik and Jay [10] analyzed climate change and human influences (water withdrawal for irrigation, reservoir manipulation, mining, and deforestation) on the Columbia River's runoff and sediment load. They identified 
that human influences contributed $8-9 \%$ to the decrease of runoff, and climate change contributed $7-8 \%$. Ahn and Merwade [30] quantified the role of climate change and human impacts on the streamflow of four states in USA, including Arizona, Georgia, Indiana, and New York, suggesting that the streamflow change of the four states caused by human activities accounted for $74 \%, 55.5 \%, 71.4 \%$, and $85.7 \%$, respectively. In China, Gao et al. [31] reported that $12.2 \%$ of the decrease in the sediment load of the middle Yellow River could be attributed to the changes in precipitation and the remaining $87.8 \%$ to human activities. For the decrease of sediment load of the Pearl River, $90 \%$ was caused by dam construction and $10 \%$ was due to climate change [26]. As a whole, the effects of human activities and climate change on runoff and sediment load vary from place to place and need to be investigated at a local scale based on watershed properties and regional environment characteristics.

As the second longest river in China, the Yellow River is noted for its relatively low water discharge as compared with its huge sediment load. Since the 1970s, the sediment discharge of the Yellow River has changed significantly, and many studies were devoted to the analysis of runoff and sediment changes in the river. The ten small tributaries, including Maobula, Buersetaigou, Heilaigou, Xiliugou, Hantaichuan, Haoqinghe, Hashenlachuan, Muhaerhe, Dongliugou, and Husitaihe, are a principal sediment source in the upper Yellow River and are adjacent to the middle Yellow River basin which is one of the regions with the most severe soil erosion in the world [32]. These tributaries originate from the Ordos Plateau, flow through the Hobq Desert, and finally enter the Yellow River [33]. The upstream of these tributaries is a loess hilly and gully region, the midstream is a desert area, and the downstream is an alluvial plain. The huge sediment output from the ten small tributaries has caused heavy sedimentation in the Inner-Mongolia reach [34-36]. So far, numerous studies have examined the characteristics of runoff and sediment load in this region [36-39], but the anthropogenic and climatic impacts on the changes of runoff and sediment load in the ten small tributaries have received less attention. Hence, we take one of the ten small tributaries, the Xiliugou basin, as a case to study the effects of climate change and human activities on the variations in the runoff and sediment load.

The objectives of this paper are as follows: (1) to analyze the variation tendency of runoff and sediment yield in the Xiliugou basin based on the hydrological records during 1960-2012 and (2) to quantify the relative effects of climate change and human activities on the streamflow and sediment load of the tributary. Better understanding of the response of the river to climate change and anthropogenic interferences might provide a theoretical basis for improving policy and plans of water and soil conservation in this sediment source area of the upper Yellow River and also give a reference for studying the same issues in other rivers.

\section{Study Area and Data}

2.1. Study Area. The Xiliugou basin is located between $109^{\circ} 24^{\prime} \sim 110^{\circ} 00^{\prime} \mathrm{E}$ and $39^{\circ} 47^{\prime} \sim 40^{\circ} 30^{\prime} \mathrm{N}$ and in the middle

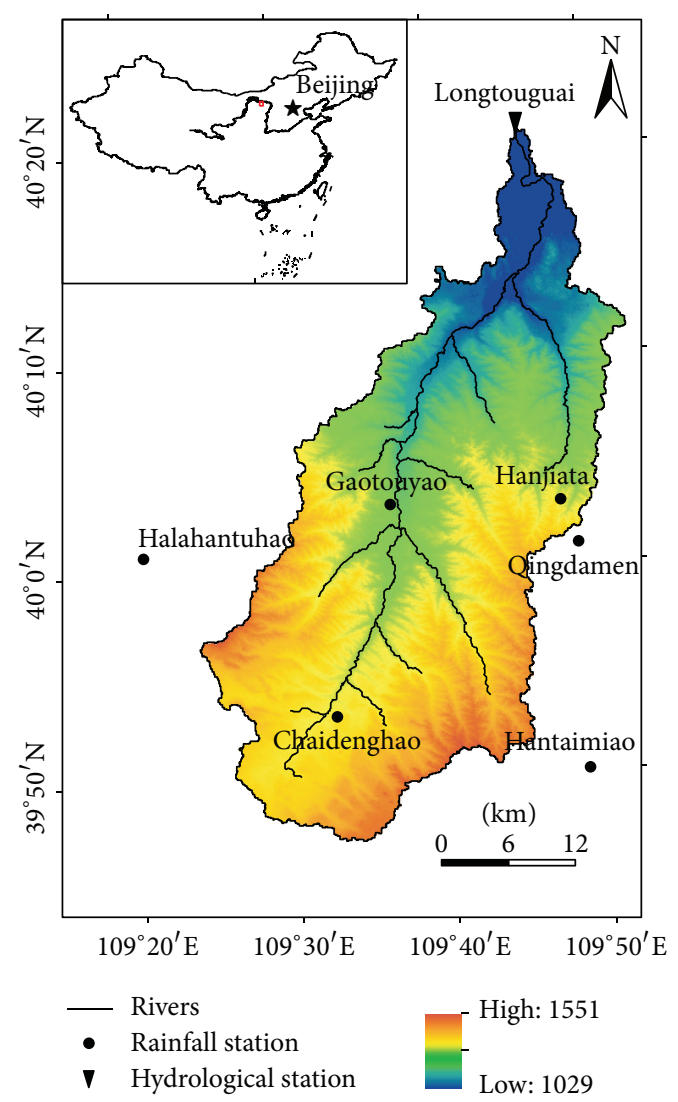

FIGURE 1: Location of the Xiliugou basin.

of the ten small tributaries (Figure 1). It has a drainage area of $1180 \mathrm{~km}^{2}$ and a fall from 1551 to $1029 \mathrm{~m}$. The watershed belongs to semiarid climate zones. It has a long and cold winter and a short and torrid summer. From November to next April, it is windy. The mean annual temperature was $6.8^{\circ} \mathrm{C}$ and the average annual precipitation was $289.6 \mathrm{~mm}$ in the period from 1960 to 2012. The distribution of monthly precipitation, runoff, and sediment load was extremely uneven and was mainly concentrated in the flood season (from June to September). Precipitation in the flood season accounted for $79.8 \%$ of the total precipitation in a year, producing $55.7 \%$ of the yearly runoff, which carried $87 \%$ of the yearly sediment load.

2.2. Data Collection. Data used in this paper include the annual runoff and sediment load (1960-2012), daily discharge and sediment concentration (1964-2012, excluding 19912005) in the flood season at Longtouguai hydrological station of the Xiliugou basin, and daily meteorological data at 17 rainfall stations and 10 weather stations from 1960 to 2012. The runoff and sediment data at Longtouguai hydrological station and precipitation data at 17 rainfall stations were collected from the Yellow River Conservancy Commission (YRCC). The meteorological data from 10 weather stations were provided by the National Climate Centre (NCC) of China Meteorological Administration (CMA). Using the IDW method in the tools of ArcGIS, the mean daily rainfall and temperature 
of the Xiliugou basin were extracted from the daily records at rainfall and weather stations. The Dongsheng weather station, which is nearest to the Xiliugou basin, was selected to obtain the wind speeds and sand-dust storms data. The sand-dust storms data supplied by the NCC of CMA cover the period from 1960 to 2007. In addition, the vegetation coverage of the Xiliugou basin was calculated from $8 \mathrm{~km}$ AVHRR (1981-2006) and $250 \mathrm{~m}$ MODIS (2000-2010) NDVI products, which were downloaded from the website of Geospatial Data Cloud (http://www.gscloud.cn/).

\section{Methods}

3.1. Trend Analysis. The Mann-Kendall (MK) test [40, 41] is one of the popular nonparametric methods for analyzing trends in hydrologic variables [30,42]. For a given time series $X\left(x_{1}, x_{2}, \ldots, x_{n}\right)$, the statistic $S$ is defined as

$$
S=\sum_{i=1}^{n} \sum_{j=i+1}^{n-1} \operatorname{sgn}\left(x_{j}-x_{i}\right)
$$

where

$$
\operatorname{sgn}\left(x_{j}-x_{i}\right)= \begin{cases}1, & x_{j}>x_{i}, \\ 0, & x_{j}=x_{i}, \\ -1, & x_{j}<x_{i} ;\end{cases}
$$

$n$ is the sample size. Once $n$ is greater than $8, S$ values will follow an approximate normal distribution [30, 43]. Its variance is calculated as

$$
\operatorname{Var}(S)=\frac{n(n-1)(2 n+S)}{18} .
$$

Then, the Mann-Kendall $Z$ is given by

$$
Z= \begin{cases}\frac{(S-1)}{\sqrt{\operatorname{Var}(S)},} & S>0, \\ 0, & S=0, \\ \frac{(S+1)}{\sqrt{\operatorname{Var}(S)},} & S<0 .\end{cases}
$$

A positive value of $Z$ indicates an increasing trend, and vice versa. The null hypothesis of no trend is rejected if $|Z|>$ 1.96 at the $5 \%$ significance level.

\subsection{Breakpoint Detection}

3.2.1. Pettitt. The Pettitt test [44] is a nonparametric method widely applied to detect the abrupt changes of water discharge and sediment load [42, 45]. For a given time series $X\left(x_{1}, x_{2}, \ldots, x_{N}\right)$, divided into two samples $x_{1}, x_{2}, \ldots, x_{t}$ and $x_{t+1}, x_{t+2}, \ldots, x_{N}$, the Pettitt test uses a version of the MannWhitney statistic $U_{t, N}$ calculated as

$$
U_{t, N}=U_{t-1, N}+\sum_{j=1}^{N} \operatorname{sgn}\left(x_{t}-x_{j}\right), \quad t=2,3, \ldots, N,
$$

where

$$
\operatorname{sgn}\left(x_{t}-x_{j}\right)= \begin{cases}1, & x_{t}>x_{j}, \\ 0, & x_{t}=x_{j}, \\ -1, & x_{t}<x_{j} .\end{cases}
$$

The breakpoint is defined to be where $\left|U_{t, N}\right|$ reaches its maximum value:

$$
K_{N}=\operatorname{Max}\left|U_{t, N}\right|, \quad(1 \leq t \leq N) .
$$

The significance level associated with $K_{N}$ is determined approximately by

$$
p \cong 2 \exp \left[\frac{-6\left(K_{N}\right)^{2}}{\left(N^{3}+N^{2}\right)}\right] .
$$

If $p<0.05$, a significant change point exists.

3.2.2. Sequential Cluster. The sequential cluster method can be used to estimate the optimal dividing point of hydrological series [46, 47]. For a given time series $X\left(x_{1}, x_{2}, \ldots, x_{n}\right)$, divided into two samples $x_{1}, x_{2}, \ldots, x_{\tau}$ and $x_{\tau+1}, x_{\tau+2}, \ldots, x_{n}$, the sum of the squared deviation before $\tau$ and after $\tau$ is defined as follows:

$$
\begin{gathered}
V_{\tau}=\sum_{i=1}^{\tau}\left(x_{i}-\overline{x_{\tau}}\right)^{2}, \\
V_{n-\tau}=\sum_{i=\tau+1}^{n}\left(x_{i}-\overline{x_{n-\tau}}\right)^{2},
\end{gathered}
$$

where

$$
\begin{aligned}
\overline{x_{\tau}} & =\frac{1}{\tau} \sum_{i=1}^{\tau} x_{i}, \\
\overline{x_{n-\tau}} & =\frac{1}{n-\tau} \sum_{i=\tau+1}^{n} x_{i} ;
\end{aligned}
$$

$\overline{x_{\tau}}$ is the average of the hydrological sequence before $\tau$ and $\overline{x_{n-\tau}}$ is the average of the hydrological sequence after $\tau$. Then, $S_{n}(\tau)$ is given by

$$
S_{n}(\tau)=V_{\tau}+V_{n-\tau}
$$

when $S_{n}(\tau)$ reaches its minimum value, $\tau$ is the optimal breakpoint.

The rank-sum test is usually used to determine the significance of the abrupt change point $[48,49]$. For a given abrupt point $\tau$, the statistic of $U$ is calculated as

$$
U=\frac{W-n_{1}\left(n_{1}+n_{2}+1\right) / 2}{\sqrt{n_{1} n_{2}\left(n_{1}+n_{2}+1\right) / 12}}
$$

where $n_{1}$ is the subsample size with fewer samples and $n_{2}$ is the subsample size with more samples. $W$ is the sum of the rank in subsample with fewer samples.

If $|U| \geqslant 1.96$, the abrupt change point is significant 
TABLE 1: Changes of annual precipitation, temperature, wind, runoff, and sediment load of the Xiliugou basin.

\begin{tabular}{|c|c|c|c|c|c|c|}
\hline Periods & $\begin{array}{c}\text { Precipitation } \\
(\mathrm{mm})\end{array}$ & $\begin{array}{c}\text { Average temperature } \\
\left({ }^{\circ} \mathrm{C}\right)\end{array}$ & $\begin{array}{l}\text { Days of strong wind } \\
\text { (days) }\end{array}$ & $\begin{array}{l}\text { Days of sand-dust storms } \\
\text { (days) }\end{array}$ & $\begin{array}{l}\text { Runoff } \\
\left(10^{4} \mathrm{~m}^{3}\right)\end{array}$ & $\begin{array}{c}\text { Sediment load } \\
\left(10^{4} \mathrm{t}\right) \\
\end{array}$ \\
\hline 1960-1969 & 297.3 & 6.2 & 74.3 & 18.3 & 3450.5 & 614.9 \\
\hline 1970-1979 & 263.0 & 6.2 & 66.5 & 17.2 & 3476.6 & 438.3 \\
\hline 1980-1989 & 248.6 & 6.3 & 29.7 & 2.5 & 2597.8 & 673.5 \\
\hline 1990-1999 & 351.4 & 7.3 & 27.3 & 1.2 & 3259.8 & 409.6 \\
\hline $2000-2012$ & 288.0 & 7.6 & 12.5 & 0.4 & 1803.2 & 101.5 \\
\hline Max & 502.5 & 8.5 & 104.0 & 45.0 & 9659.0 & 4749.0 \\
\hline Min & 109.0 & 5.0 & 3.0 & 0.0 & 736.2 & 0.01 \\
\hline Average & 289.6 & 6.8 & 40.4 & 7.5 & 2854.5 & 428.0 \\
\hline$C_{v}$ & 0.3 & 0.1 & 0.7 & 1.3 & 0.7 & 1.9 \\
\hline
\end{tabular}

3.3. Separating the Impacts of Climate Change and Human Activities on Streamflow and Sediment Load. By the abrupt changes identified, the runoff and sediment load series are divided into two periods. The first period is regarded as the natural period or reference period and the second period is regarded as the measure period or impact period. Following previous studies [50], we separated the effects of human activities and climate change on runoff and sediment load in the second period by comparing with runoff and sediment load in the reference period. The separation approach can be described by the following equations:

$$
\begin{aligned}
& W_{T}=W_{I}-W_{N}, \\
& W_{C}=W_{S}-W_{N}, \\
& W_{H}=W_{T}-W_{C}, \\
& \eta_{H}=\frac{W_{H}}{W_{T}} \times 100 \%, \\
& \eta_{C}=\frac{W_{C}}{W_{T}} \times 100 \%,
\end{aligned}
$$

where $W_{T}$ is the total runoff or sediment load variation and $W_{I}$ and $W_{N}$ are the average observed runoff or sediment load in the impact period and natural period, respectively. $W_{C}$ is the runoff or sediment load variation caused by climate impact, $W_{S}$ is the simulated virgin runoff or sediment load from the basin with the same land cover as that in the reference period by the rainfall in the impact period, $W_{H}$ is the runoff or sediment load variation caused by human activities, and $\eta_{H}$ and $\eta_{C}$ measure the relative impacts of human activities and climate change on runoff or sediment load, respectively.

The double mass curves between annual precipitation and runoff/sediment load can reflect the impacts of human activities [15, 31]. Here, we use the regression equations established from the double mass curves of precipitation versus runoff and precipitation versus sediment load in the natural period to calculate the annual runoff and sediment load in the impact period $\left(W_{S}\right)$.

\section{Results}

4.1. Changes in Precipitation, Temperature, Wind, Runoff, and Sediment Load. Figure 2 shows trends of runoff, sediment load, and meteorological indices, estimated by the MK test. Overall, the runoff, sediment discharge, and annual days of strong wind (daily wind speed $\geq 5 \mathrm{~m} / \mathrm{s}$ ) and sand-dust storms decreased significantly at the $99 \%$ confidence level with the $Z$ value at $-2.65,-2.57,-7.93$, and -6.67 , respectively, while the mean annual temperature increased significantly at the $99 \%$ confidence level with a $Z$ value of 5.1. For the precipitation series, no significant trend was detected.

For investigating the decadal changes of the six variables, the mean of each variable in each decade was calculated (Table 1). The results indicate that the runoff, sediment discharge, precipitation, temperature, and annual days of strong wind and sand-dust storms of the Xiliugou basin changed obviously during the period 1960-2012, especially for sediment discharge which fluctuated in the range of 0.01-4749 t/a with an average of $428 \mathrm{t} / \mathrm{a}$ and a coefficient of variance $\left(C_{v}\right)$ as high as 1.9. Moreover, regarding the sediment discharge during 1960-1969 as the reference value, except the 1980s, the sediment discharge during the 1970s, 1990s, and 2000-2012 decreased by $28.7 \%, 33.4 \%$, and $83.5 \%$, respectively. For the annual runoff, a considerable reduction up to $47.7 \%$ occurred in the period 2000-2012. The annual days of strong wind and sand-dust storms decreased continuously during the last four decades (from the year 1970 to 2012). The maximum change of the annual days of strong wind and sand-dust storms occurred in the period 2000-2012, in which the annual days of strong wind and sand-dust storms decreased by $83.1 \%$ and $97.9 \%$, respectively. By contrast, the mean annual temperature increased gradually during the last three decades, especially in the 1990s and 2000-2012. The decadal means of annual precipitation ranged from 248.6 to $351.4 \mathrm{~mm}$ with no noticeable trend.

4.2. Abrupt Change Analysis. The abrupt changes in runoff and sediment load recorded at Longtouguai hydrological station during 1960-2012 were examined using Pettitt test. Figure 3 shows the changes of $K$ statistic of Pettitt test during the period 1960-2012. Obviously, abrupt changes appeared 


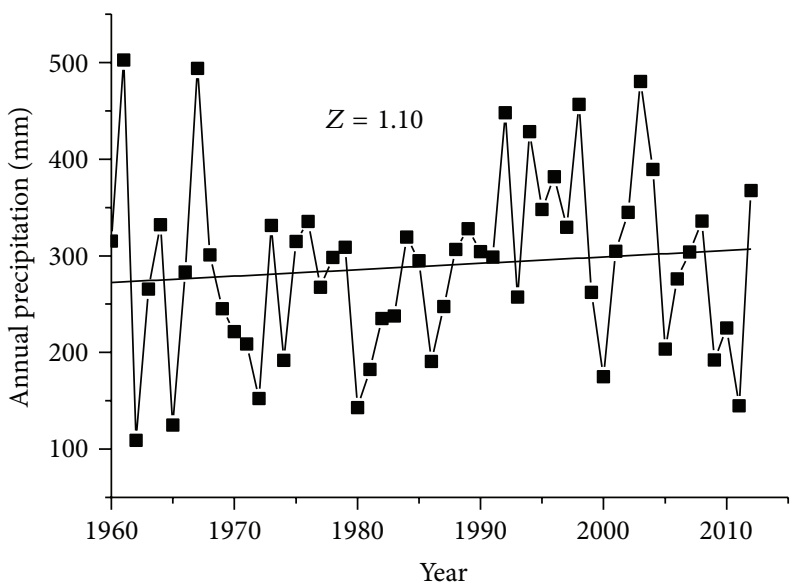

(a)

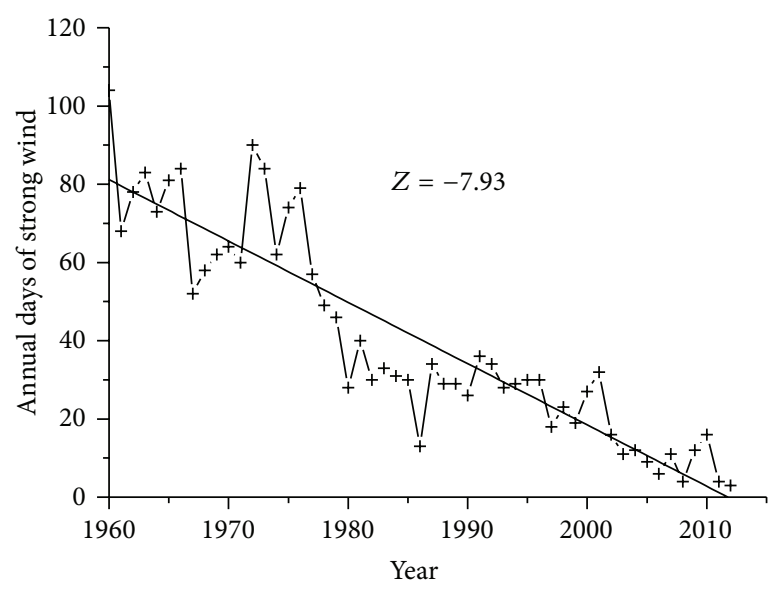

(c)

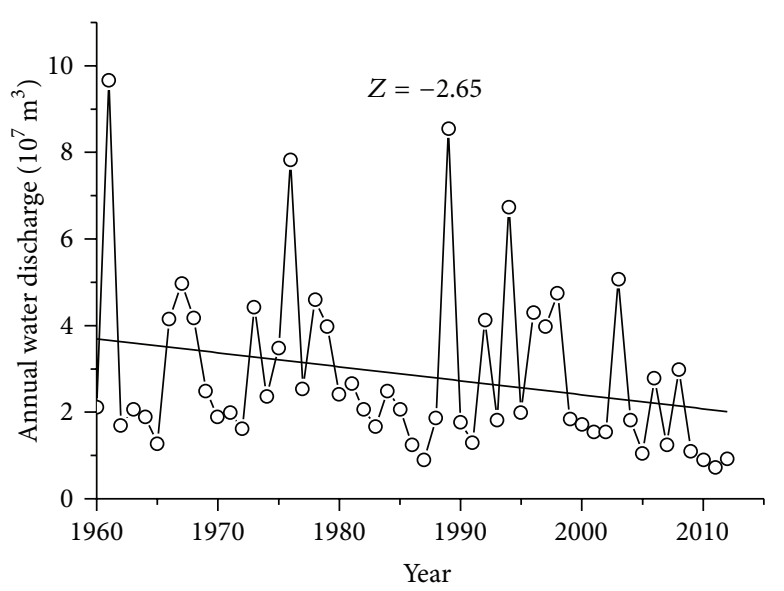

(e)

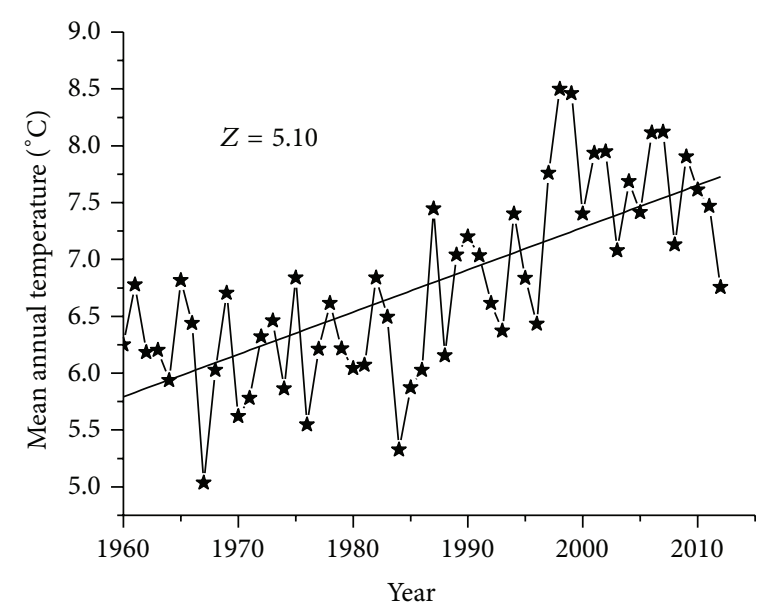

(b)

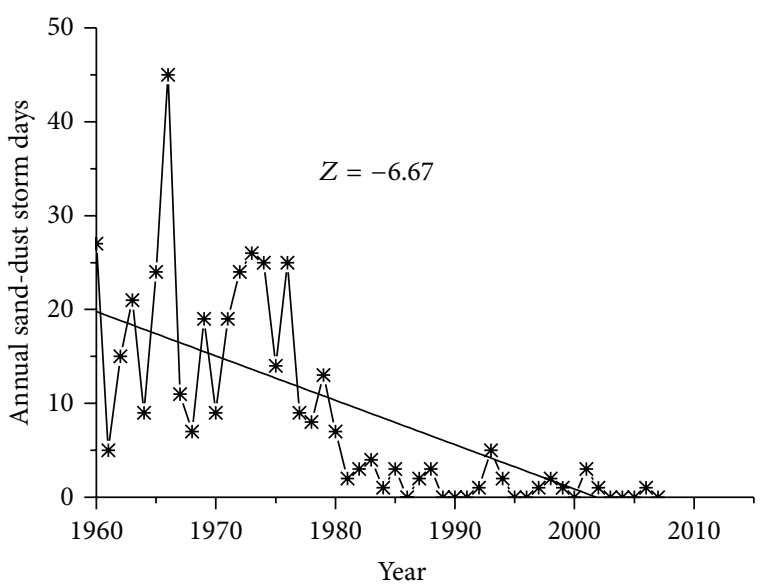

(d)

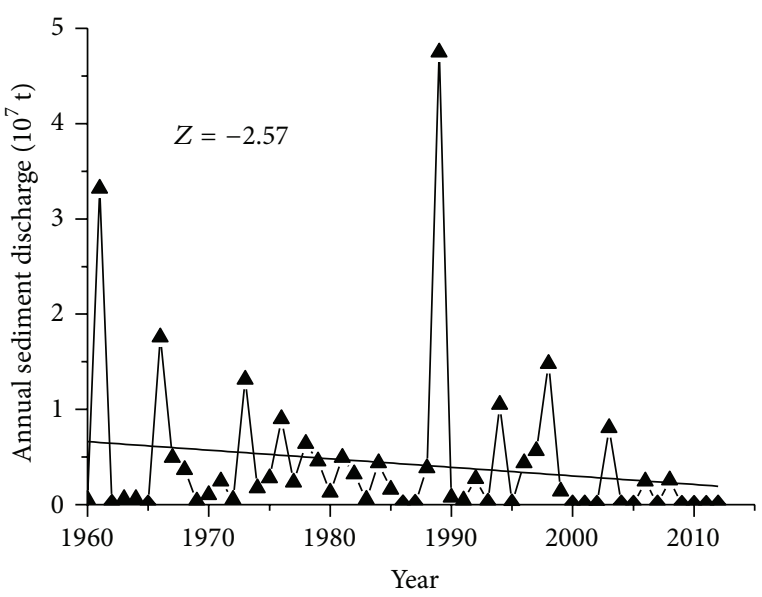

(f)

FIGURE 2: Trends of precipitation, temperature, wind, runoff, and sediment load $(|Z| \geq 1.96, p<0.05 ;|Z| \geq 2.576, p<0.01)$.

in 1998 in both the runoff and sediment load series. The abrupt change in the sediment load series is statistically significant with a $p$ value of 0.007 , but that in the runoff series has a $p$ value of 0.052 . In this case, the sequential cluster method was adopted to further detect the abrupt change points in the runoff series. Figure 4 shows the changes in $S_{n}(\tau)$ during the period 1960-2012. Again, the point in 1998 is the lowest. By applying the rank-sum test to the abrupt change point in 1998, it is proved that the abrupt change point is statistically significant with a $U$ value of -3.12 . According to 


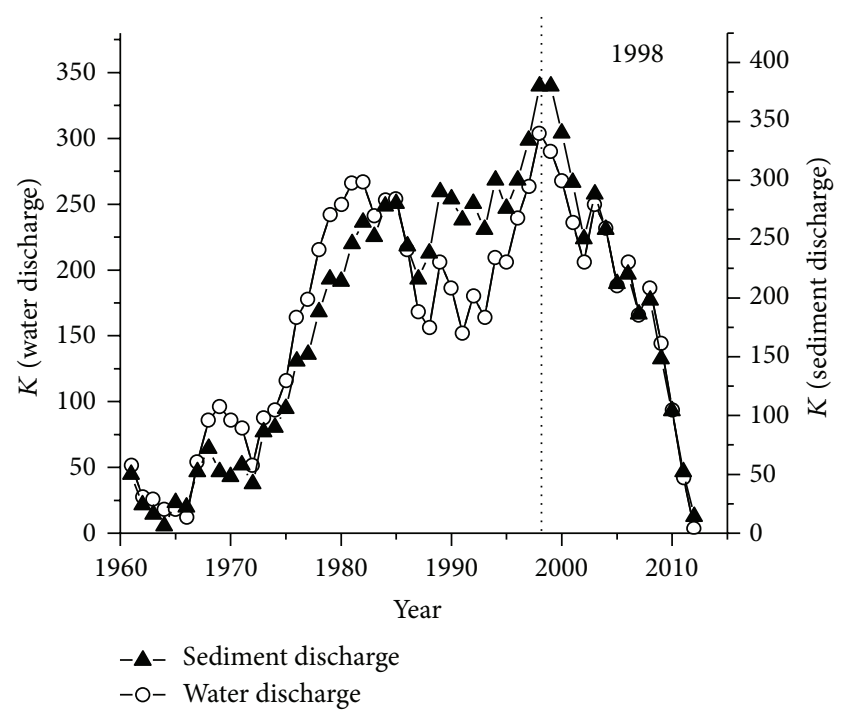

FIgURE 3: Abrupt changes in annual runoff and sediment load in 1960-2012 (by Pettitt test).

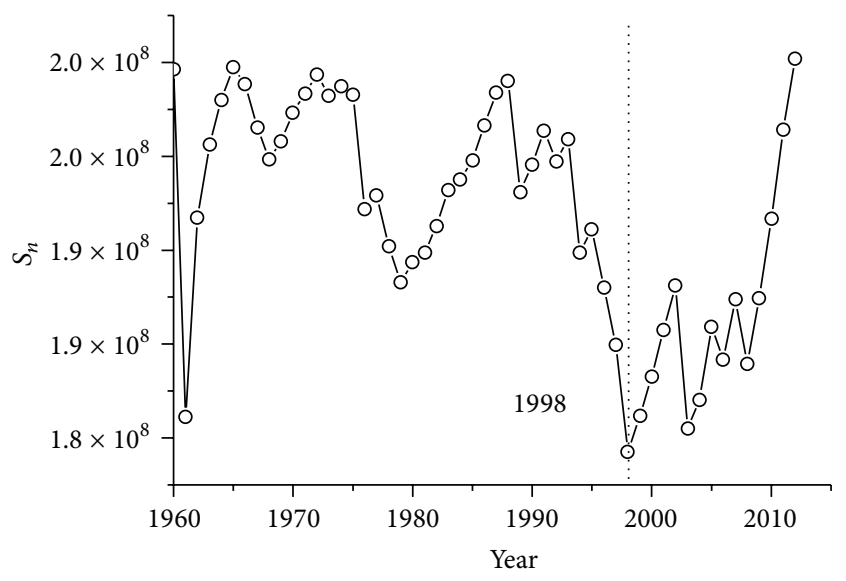

FIGURE 4: Abrupt changes in annual runoff in 1960-2012 (by sequential cluster test).

these breakpoints, the study period for runoff and sediment load and all influencing variables in the Xiliugou catchment was divided into the natural period (1960-1998) and the impact period (1999-2012).

4.3. Separating Climatic and Anthropogenic Impacts on Annual Water Discharge and Sediment Load. The Xiliugou basin belongs to the region where wind-water two-phase coupling processes prevail. Therefore, hydroclimatic variables including precipitation, temperature, and annual days of strong wind and sand-dust storms were considered to analyze the effects of climate change on runoff and sediment load variations. The correlation coefficients between runoff, sediment load, and meteorological indices were calculated by SPSS19 software (Table 2). The statistics demonstrate that precipitation is the key factor affecting runoff and sediment load.
To define a better relationship between precipitation and runoff and that between precipitation and sediment discharge, we investigated the performance of six categories of annual precipitation, which are the sums of different daily rainfall $(\geq 0 \mathrm{~mm}, \geq 5 \mathrm{~mm}, \geq 10 \mathrm{~mm}, \geq 15 \mathrm{~mm}, \geq 20 \mathrm{~mm}$, and $\geq 30 \mathrm{~mm}$ ). Table 3 shows the statistics of the runoff, sediment load, and six categories of annual precipitation by SPSS19. The correlation coefficients between runoff and the six categories of annual precipitation are $0.60,0.64,0.69,0.74,0.77$, and 0.75 , respectively, and the correlation coefficients between sediment load and the six categories of annual precipitation are $0.39,0.43,0.48,0.51,0.53$, and 0.54 , respectively. All the correlation coefficients are significant at the 0.01 level. The runoff is best correlated with the fifth category, which is the annual sum of daily rainfall $\geq 20 \mathrm{~mm}$, and the sediment load is best correlated with the sixth category, which is the annual sum of daily rainfall $\geq 30 \mathrm{~mm}$. Considering that the correlation coefficients between the annual sediment load and the fifth category and between the annual sediment load and the sixth category are nearly the same, the annual rainfall series with daily rainfall $\geq 20 \mathrm{~mm}$ was selected to analyze the effects of climate change on both the runoff and sediment load.

Using the annual precipitation of daily rainfall $\geq 20 \mathrm{~mm}$, double mass curves of rainfall versus runoff and rainfall versus sediment load for the reference period of 1960-1998 were plotted in Figure 5. Linear regression relations of the double mass curves were also shown in Figure 5 and could be represented by

$$
\begin{aligned}
\Sigma Q & =27.862 \Sigma P-1079.9, \\
\Sigma S & =4.3707 \Sigma P+343.09,
\end{aligned}
$$

where $\Sigma Q$ is the cumulative runoff discharge, $\Sigma P$ is the cumulative precipitation, and $\Sigma S$ is the cumulative sediment discharge.

Based on (14), the annual virgin streamflow and sediment discharge under the rainfall in the period 1999-2012 were calculated. Then, the effects of climate change and human activities on runoff and sediment load in the impact period 1999-2012 were separated using (13). The results are shown in Tables 4 and 5. Comparing with the natural period (19601998), the mean annual runoff and sediment load in the impact period decreased by $44.1 \%$ and $80.9 \%$, respectively. Clearly, the rate of sediment load reduction is much greater than that of runoff reduction. For the runoff reduction, human activities made a contribution of $68 \%$ and the remaining $32 \%$ was associated with climate change. In contrast, the anthropogenic impacts contributed $75 \%$ to the sediment load reduction, and the climate change was responsible for the remaining $25 \%$. Thus, human activities had been the dominant influence factor for both the runoff and sediment load reductions in the Xiliugou basin.

\section{Discussion}

5.1. Impacts of Climate Change. As disclosed in Table 2, both the runoff and sediment load are more closely related with precipitation in the Xiliugou basin. Thus, when there was 
TABle 2: Correlation coefficients between annual runoff, sediment load, and meteorological indices.

\begin{tabular}{lcccc}
\hline & Annual precipitation & Mean annual temperature & Annual days of strong wind & Annual days of sand-dust storms \\
\hline Runoff & $0.61^{* *}$ & -0.14 & 0.13 & 0.22 \\
Sediment & $0.40^{* *}$ & 0.01 & 0.08 & 0.12 \\
\hline
\end{tabular}

${ }^{* *}$ Significant at the 0.01 level.

TABLE 3: Correlation coefficients between annual runoff, sediment load, and precipitation with different daily precipitation thresholds.

\begin{tabular}{lcccccc}
\hline & & \multicolumn{4}{c}{ Categories of rainfall (mm) } \\
& Daily rainfall $\geq 0$ & Daily rainfall $\geq 5$ & Daily rainfall $\geq 10$ & Daily rainfall $\geq 15$ & Daily rainfall $\geq 20$ & Daily rainfall $\geq 30$ \\
\hline Runoff & $0.60^{* *}$ & $0.64^{* *}$ & $0.69^{* *}$ & $0.74^{* *}$ & $0.77^{* *}$ & $0.75^{* *}$ \\
Sediment & $0.39^{* *}$ & $0.43^{* *}$ & $0.48^{* *}$ & $0.51^{* *}$ & $0.53^{* *}$ & $0.54^{* *}$ \\
\hline
\end{tabular}

${ }^{* *}$ Significant at the 0.01 level.

TABLE 4: Contributions of precipitation variation and human activities to changes in runoff.

\begin{tabular}{|c|c|c|c|c|c|c|c|}
\hline \multirow{2}{*}{ Period } & \multirow{2}{*}{$\begin{array}{l}\text { Precipitation } \\
(\mathrm{mm})\end{array}$} & \multirow{2}{*}{$\begin{array}{l}\text { Observed runoff } \\
\qquad W_{I}\left(10^{4} \mathrm{~m}^{3}\right)\end{array}$} & \multirow{2}{*}{$\begin{array}{l}\text { Simulated virgin runoff } \\
\qquad W_{S}\left(10^{4} \mathrm{~m}^{3}\right)\end{array}$} & \multicolumn{2}{|c|}{ Effect of precipitation } & \multicolumn{2}{|c|}{ Effect of human activities } \\
\hline & & & & $W_{C}\left(10^{4} \mathrm{~m}^{3}\right)$ & $\eta_{C}(\%)$ & $W_{H}\left(10^{4} \mathrm{~m}^{3}\right)$ & $\eta_{H}(\%)$ \\
\hline 1960-1998 & 119.45 & 3231.05 & - & - & - & - & - \\
\hline 1999-2012 & 99.34 & 1805.58 & 2767.78 & -463.27 & $32 \%$ & -962.20 & $68 \%$ \\
\hline
\end{tabular}

TABLE 5: Contributions of precipitation variation and human activities to changes in sediment load.

\begin{tabular}{|c|c|c|c|c|c|c|c|}
\hline \multirow{2}{*}{ Period } & \multirow{2}{*}{$\begin{array}{l}\text { Precipitation } \\
(\mathrm{mm})\end{array}$} & \multirow{2}{*}{$\begin{array}{l}\text { Observed sediment load } \\
\qquad W_{I}\left(10^{4} \mathrm{t}\right)\end{array}$} & \multirow{2}{*}{$\begin{array}{l}\text { Simulated virgin sediment load } \\
\qquad W_{S}\left(10^{4} \mathrm{t}\right)\end{array}$} & \multicolumn{2}{|c|}{ Effect of precipitation } & \multicolumn{2}{|c|}{ Effect of human activities } \\
\hline & & & & $W_{C}\left(10^{4} \mathrm{t}\right)$ & $\eta_{C}(\%)$ & $W_{H}\left(10^{4} \mathrm{t}\right)$ & $\eta_{H}(\%)$ \\
\hline 1960-1998 & 119.45 & 544.21 & - & - & - & - & - \\
\hline 1999-2012 & 99.34 & 104.13 & 434.18 & -110.02 & $25 \%$ & -330.05 & $75 \%$ \\
\hline
\end{tabular}

TABLE 6: Differences of precipitation, runoff, and sediment load of the Xiliugou basin between natural period and impact period.

\begin{tabular}{|c|c|c|c|c|c|c|c|c|}
\hline & $\begin{array}{l}\text { Annual } \\
\text { runoff } \\
\left(10^{4} \mathrm{~m}^{3}\right)\end{array}$ & $\begin{array}{c}\text { Annual } \\
\text { sediment } \\
\text { load } \\
\left(10^{4} \mathrm{t}\right)\end{array}$ & $\begin{array}{c}\text { Daily rainfall } \\
\quad \geq 0 \\
(\mathrm{~mm})\end{array}$ & $\begin{array}{c}\text { Daily rainfall } \\
\quad \geq 5 \\
(\mathrm{~mm})\end{array}$ & $\begin{array}{c}\text { Daily rainfall } \\
\quad \geq 10 \\
(\mathrm{~mm})\end{array}$ & $\begin{array}{c}\text { Daily rainfall } \\
\quad \geq 15 \\
(\mathrm{~mm})\end{array}$ & $\begin{array}{l}\text { Daily rainfall } \\
\quad \geq 20 \\
(\mathrm{~mm})\end{array}$ & $\begin{array}{c}\text { Daily rainfall } \\
\quad \geq 30 \\
(\mathrm{~mm})\end{array}$ \\
\hline 1960-1998 & 3231.1 & 544.2 & 290.8 & 239.5 & 184.1 & 146.4 & 119.5 & 92.2 \\
\hline 1999-2012 & 1805.6 & 104.1 & 286.1 & 230.0 & 172.2 & 128.7 & 99.3 & 75.0 \\
\hline $\begin{array}{l}\text { Percentage of } \\
\text { change }\end{array}$ & $-44.1 \%$ & $-80.9 \%$ & $-1.6 \%$ & $-4.0 \%$ & $-6.5 \%$ & $-12.1 \%$ & $-16.8 \%$ & $-18.6 \%$ \\
\hline
\end{tabular}

a reduction in rainfall in the period from 1999 to 2012, it was expected that a fall occurred in runoff and sediment load. The runoff and sediment load of the basin decreased by $44.1 \%$ and $80.9 \%$, respectively (Table 6 ). To the total reductions of runoff and sediment load, as mentioned above, the contributions of climate change were estimated to be $32 \%$ and $25 \%$, respectively. This means that the rainfall decrease in the years from 1999 to 2012 induced a reduction of $14.1 \%$ in runoff and a reduction of $20.2 \%$ in sediment load in the basin. Nevertheless, it is not the changes of all sizes of rainfall strength that are responsible for the reduction of runoff or sediment load. Table 3 shows that the annual runoff and sediment load are more closely related with the annual precipitation of the higher daily rainfall. In other words, the runoff and sediment load in the Xiliugou basin are sensitive to rainfall intensity. Hence, it is the reduction of storm and heavy storm rainfalls that induces the reduction of the runoff and sediment load. The annual precipitation of the daily rainfall $\geq 20 \mathrm{~mm}$, used in this study for deriving the effect of climate change, decreases by $16.8 \%$ (Table 6). Thus, a decrease of effective rainfalls tends to cause a bit lower percentage (14.1\%, as given above) of runoff reduction and a slightly higher portion $(20.2 \%)$ of sediment load reduction in the Xiliugou basin.

Many previous studies used the total annual rainfall to investigate the contributions of precipitation change to runoff and sediment variations [11, 15, 29, 31, 50-53]. However, in arid and semiarid regions, the rainfall intensity is important for runoff generation and soil erosion [21]. As stated above, we choose the annual rainfall series with daily rainfall $\geq 20 \mathrm{~mm}$ to estimate the effects of precipitation change on runoff and sediment load based on the correlation coefficients between 
TABLE 7: Contributions of precipitation variation and human activities to changes in runoff and sediment load with different daily precipitation thresholds.

\begin{tabular}{lcccc}
\hline \multirow{2}{*}{ Categories of rainfall $(\mathrm{mm})$} & \multicolumn{2}{c}{ Runoff } & \multicolumn{2}{c}{ Sediment load } \\
& Effect of precipitation & Effect of human activities & Effect of precipitation & Effect of human activities \\
\hline Daily rainfall $\geq 0$ & $2.9 \%$ & $97.1 \%$ & $9.4 \%$ & $90.6 \%$ \\
Daily rainfall $\geq 5$ & $7.4 \%$ & $92.6 \%$ & $11.8 \%$ & $88.2 \%$ \\
Daily rainfall $\geq 10$ & $10.6 \%$ & $89.4 \%$ & $13.6 \%$ & $86.4 \%$ \\
Daily rainfall $\geq 15$ & $21.1 \%$ & $78.9 \%$ & $19.1 \%$ & $80.9 \%$ \\
Daily rainfall $\geq 20$ & $32.5 \%$ & $67.5 \%$ & $25.0 \%$ & $75.0 \%$ \\
Daily rainfall $\geq 30$ & $19.7 \%$ & $80.3 \%$ & $27.9 \%$ & $72.1 \%$ \\
\hline
\end{tabular}

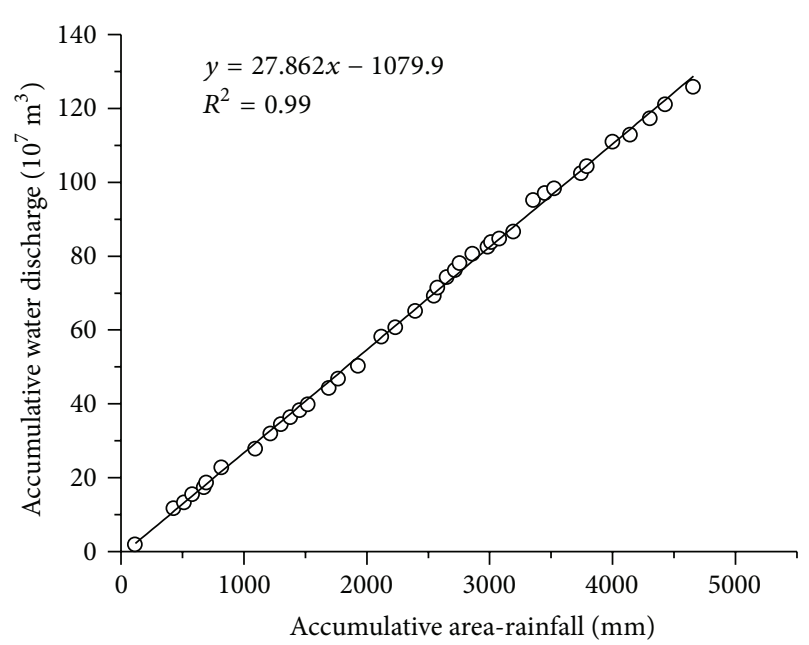

(a)

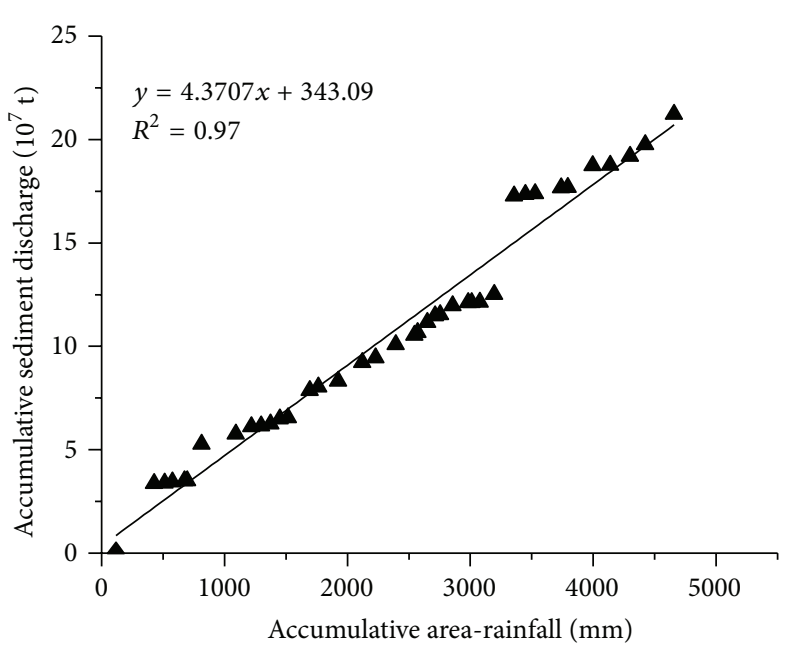

(b)

FIGURE 5: Regression relations of cumulative precipitation (daily precipitation $\geq 20 \mathrm{~mm}$ ) with cumulative runoff and sediment load in 1960 1998.

the six categories of annual precipitation and runoff/sediment load. Here, to illustrate the importance of selecting a proper category of annual rainfall, we made an investigation about the effects of adopting annual rainfall with different intensities on the estimated contributions of rainfall changes to runoff and sediment variations. As shown in Table 7, the effects of precipitation change on the deviations of runoff and sediment load vary with different categories of annual precipitation. For runoff, except the sixth category, the contribution rate by rainfall changes increased gradually while that by human activities declined correspondingly. Comparing the percentage of change of the rainfall in Table 6 with the contribution rates of different annual precipitation categories in Table 7, we can find that the contribution rates by precipitation variation increase with the percentage of change of annual rainfall in different categories between natural period and the impact period. We think that the lower contribution rates derived from the first four annual precipitation categories underestimate the effects of climate change. The reasons are that the rainfall with a low intensity may not generate runoff in this semiarid basin. When the amount of rainfall with a low intensity does not change noticeably from the first to the second period as illustrated by the lower differences of the first four annual precipitation categories between the two periods, the lower difference of the total of both low and high rainfall between the two periods will dampen the true effects of changes in high runoff-generating rainfall on runoff variations. As to the exception in the case of the sixth category, it might be the result of excluding some rainfall which can generate runoff. For the sediment load, the contribution rates by rainfall changes also increase gradually with rainfall intensity. Again, the lower contribution rates derived from the first four annual precipitation categories underestimate the effects of climate change for the same reasons. Therefore, when we calculate the contributions of precipitation and human activities to the changes in runoff and sediment load, we should consider the influences of rainfall intensity to avoid overestimating or underestimating the contribution by rainfall variation.

5.2. Impacts of Human Activities. In this paper, the anthropogenic contributions to runoff and sediment load reductions in one of the ten small tributaries were found to be $68 \%$ and 75\%, respectively, during 1999-2012. These estimates are consistent with those given in previous studies for watersheds in the middle Yellow River, which is located on the south of the ten small tributaries. Since the late 1970s, the streamflow and sediment load in the Yellow River basin have decreased 


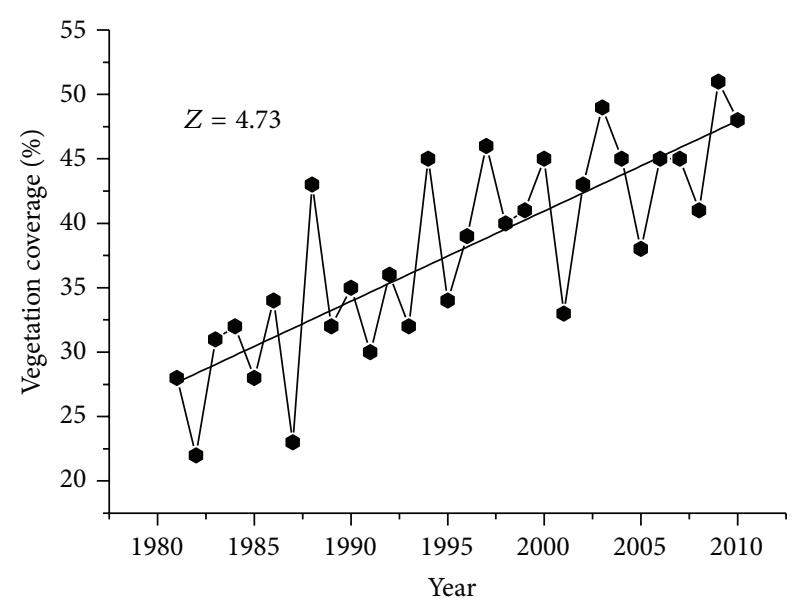

Figure 6: Changes of vegetation coverage in the Xiliugou basin.

greatly owing to anthropogenic impacts such as building dams and soil-water conservations $[4,27,31]$. The study by Gao et al. [31] suggested that human activities were responsible for $72 \%$ and $87.8 \%$ of the runoff and sediment load decreases in the middle Yellow River basin. For the Wuding River, which is one of the large tributaries in the middle Yellow River, it was estimated that the human activities accounted for $70 \%$ of the runoff reduction [47] and $88.9 \%$ of the sediment decrease [51]. Liang et al. [52] addressed that human activities contributed $60 \%$ to the streamflow decrease in the Kuye River basin in the north part of the middle Yellow River. In another tributary of the middle Yellow River, the Huangfuchuan River basin, 70\% of the runoff decline was related to human activities [53]. All these studies indicated that human activities had become the dominant influence factor for the reductions of runoff and sediment load in the middle Yellow River in recent decades and this study finds the same phenomenon in the upper reaches of the Yellow River.

Soil and water conservation measures were implemented in the Yellow River basin as early as the 1950s and intensified in the late 1970s [27]. In contrast, the soil and water conservation measures were applied to the Xiliugou basin in a later period [54]. By the end of 2007, 26,020 ha of forests and 976 ha of grass had been planted, 2,100 ha of enclosure had been built, and the number of check dams reached 47 [55]. The total conservation area accounted for approximately $37.80 \%$ of the total basin area. Based on the AVHRR-NDVI and MODIS-NDVI data, the vegetation coverage in the Xiliugou watershed in the period from 1981 to 2010 was calculated by using the dimidiate pixel model [56]. Clearly, the vegetation coverage in the Xiliugou basin increased significantly from 1981 to 2010 (Figure 6). The mean vegetation coverage in the period of $1999-2010$ reached $44 \%$, increased by $10 \%$ compared with the period of 1981-1998. As shown in Figure 2 and Table 6 , there was not a significant increasing trend in precipitation in the Xiliugou basin but a noticeable reduction in the years of 1999-2012. Considering that water availability is the control element for vegetation growth in this semiarid region, the rise of vegetation coverage in the basin could be attributed principally to the implementation of conservation

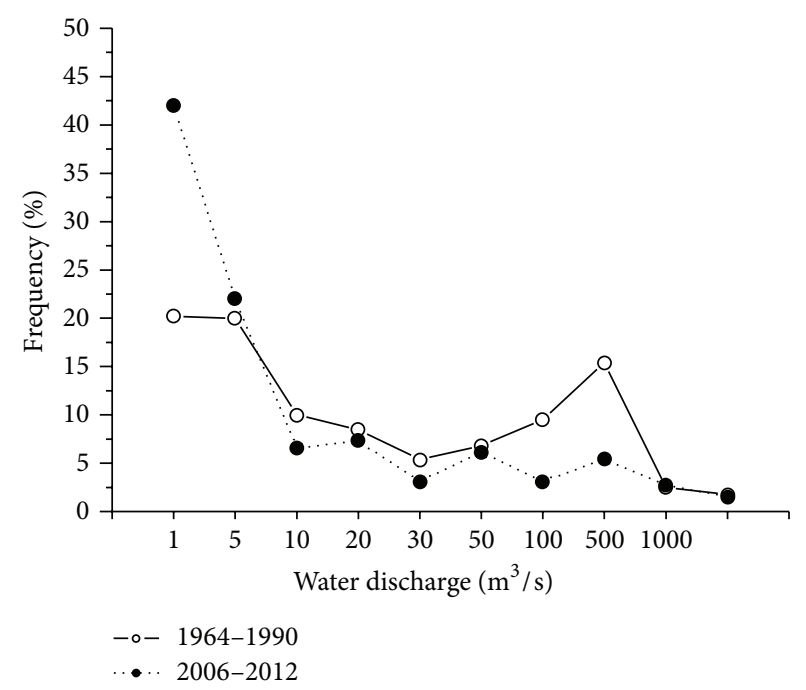

FIGURE 7: Frequency distribution of discharge.

measures including afforestation, grass-planting, and enclosure. Thus, it is soil and water conservation measures that have played an important role in the reduction of the runoff and sediment yield in the Xiliugou basin.

\subsection{Changes of Water-Sediment Relation and Flow Frequency} Distribution and Some Implications. A reduction of runoff in the impact period in the Xiliugou basin has been revealed above. Nevertheless, this is not applicable to the full water discharge spectrum. Figure 7 shows the frequency distribution of different categories of water discharge in both the reference and impact periods. It is demonstrated that, during the impact period, the frequency of discharge between 0 and $5 \mathrm{~m}^{3} / \mathrm{s}$ increased and that between 5 and $1000 \mathrm{~m}^{3} / \mathrm{s}$ decreased. For the water discharge larger than $1000 \mathrm{~m}^{3} / \mathrm{s}$, the frequency changed little. This discrepancy in the changes of flows in different size intervals can also be attributed to the implementation of soil and water conservation measures. As mentioned above, the vegetation coverage in Xiliugou basin increased significantly from 1981 to 2010 owing to the soil and water conservation practices (Figure 6). By intercepting precipitation, enhancing evaporation, and increasing infiltration, vegetation can reduce the total runoff but may elevate the runoff of low flows. This should be the main reason for the increase of water discharge in the range of $0-5 \mathrm{~m}^{3} / \mathrm{s}$ and the decrease of flows within $5-1000 \mathrm{~m}^{3} / \mathrm{s}$.

Clearly, in the Xiliugou basin, it is reasonable to reach the fact that the reduction of sediment load mainly results from the decrease of moderate flows, which are the events, as stated by Wolman and Miller [57], that tend to carry the largest portion of sediment in most rivers. Consequently, with the reduction of moderate flows and the increase of low flows, a higher portion of sediment load than that for runoff was reduced during the impact period.

Besides the discrepancy of runoff changes for different flows, the higher percentage of sediment load reduction than runoff (indicated by $80.9 \%$ versus $44.1 \%$ ) in the impact 


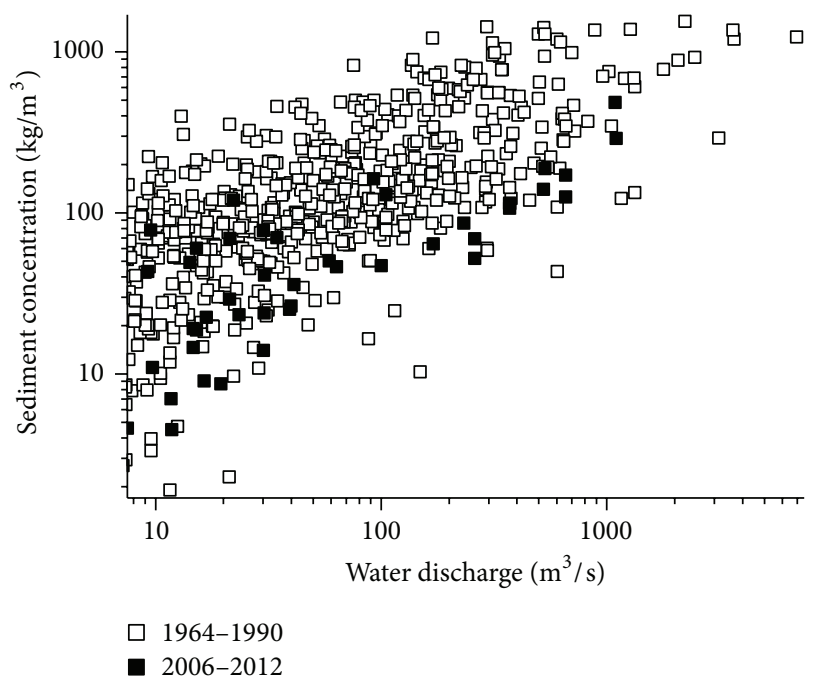

FIGURE 8: The relationship of discharge and sediment concentration.

period must be also partly associated with the changes in the relation between water discharge and sediment concentration (the water-sediment relation). The scatter plot between daily discharge and sediment concentration in the flood season is shown in Figure 8. It can be seen that the sediment concentration in the impact period was much lower than that in the natural period at the same water discharge in the range $300-1100 \mathrm{~m}^{3} / \mathrm{s}$. This means that the reduced flows in the impact period carried a much lower sediment load. The reduction in sediment concentration for the same water discharge should be the result of reduced sediment yield on the slopes under the same climate, which have been applied with soil and water conservation measures. Therefore, the implementation of soil and water conservation measures in the basin has been the principal cause for a higher portion of sediment load reduction and a higher contribution of human activities to the reduction than those for the runoff in the Xiliugou basin in the period of 1999-2012.

\section{Conclusions}

In this study, we analyzed the patterns of change in the runoff and sediment load in the Xiliugou basin from 1960 to 2012 and separated the effects of climate change and human activities on the reductions of runoff and sediment load in 1999-2012. Our conclusions are as follows.

(1) The annual runoff and sediment load of this basin decreased significantly at the $99 \%$ confidence level during the period 1960-2012, while no significant trend was detected in the annual precipitation. According to the abrupt changes in 1998 identified in the runoff and sediment series, the years from 1960 to 2012 were divided into two periods: $1960-1998$ and 1999-2012. Comparing with the period 1960-1998, the runoff and sediment load over 1999-2012 reduced by $44.1 \%$ and $80.9 \%$, respectively.
(2) Human activities were the major drivers of the runoff and sediment load variations in the Xiliugou basin recently. They induced $68 \%$ and $75 \%$, respectively, of the reductions of runoff and sediment load during 1999-2012, while climate change was responsible for the remaining reductions.

(3) Different contribution rates of rainfall changes to the deviations of runoff and sediment load could be produced by using different categories of annual precipitation, so we should pay attention to the effects of rainfall intensity to avoid overestimating or underestimating the contributions of rainfall changes to the variations of runoff and sediment load.

(4) A further inspection on the changes in flow frequency distribution and the water-sediment relation indicated that the implementation of soil and water conservation measures should be the main reason for the phenomenon that the frequency of flows between 0 and $5 \mathrm{~m}^{3} / \mathrm{s}$ increased and that between 5 and $1000 \mathrm{~m}^{3} / \mathrm{s}$ decreased during the impact period and also for the sediment load reduction and the contribution of human activities to the reduction being much higher than those for the runoff.

\section{Conflict of Interests}

The authors declare that there is no conflict of interests regarding the publication of this paper.

\section{Acknowledgments}

This work was supported by the National Natural Science Foundation of China (Grant no. 41371036), the National Major Basic Research Program of China (Grant no. 2011CB403305), and the Ministry of Science and Technology of China (Grant no. 2013 DFA91700). The authors thank Dr. Mischke and the anonymous reviewer for the precious and helpful comments.

\section{References}

[1] D. Qin, G. K. Plattner, M. Tignor et al., Climate Change 2013: The Physical Science Basis, Cambridge University Press, Cambridge, UK, 2014.

[2] N. W. Arnelf and N. S. Reynard, "The effects of climate change due to global warming on river flows in Great Britain," Journal of Hydrology, vol. 183, no. 3-4, pp. 397-424, 1996.

[3] S. Zhang, X. X. Lu, D. L. Higgitt, C.-T. A. Chen, J. Han, and H. Sun, "Recent changes of water discharge and sediment load in the Zhujiang (Pearl River) Basin, China," Global and Planetary Change, vol. 60, no. 3-4, pp. 365-380, 2008.

[4] C. Miao, J. Ni, and A. G. L. Borthwick, "Recent changes of water discharge and sediment load in the Yellow River basin, China," Progress in Physical Geography, vol. 34, no. 4, pp. 541-561, 2010.

[5] J. Němec and J. Schaake, "Sensitivity of water resource systems to climate variation," Hydrological Sciences Journal, vol. 27, no. 3, pp. 327-343, 1982. 
[6] N. W. Arnell, "Climate change and global water resources: SRES emissions and socio-economic scenarios," Global Environmental Change, vol. 14, no. 1, pp. 31-52, 2004.

[7] P. C. D. Milly, K. A. Dunne, and A. V. Vecchia, "Global pattern of trends in streamflow and water availability in a changing climate," Nature, vol. 438, no. 7066, pp. 347-350, 2005.

[8] I.-W. Jung and H. Chang, "Assessment of future runoff trends under multiple climate change scenarios in the Willamette River Basin, Oregon, USA," Hydrological Processes, vol. 25, no. 2, pp. 258-277, 2011.

[9] U. Scherer, K. Gerlinger, and E. Zehe, "Modeling climate change impact on surface runoff, erosion and sediment yield in agriculturally used catchments," in Proceedings of the EGU General Assembly Conference Abstracts, vol. 12, p. 5864, Vienna, Austria, May 2010.

[10] P. K. Naik and D. A. Jay, "Distinguishing human and climate influences on the Columbia River: changes in mean flow and sediment transport," Journal of Hydrology, vol. 404, no. 3-4, pp. 259-277, 2011.

[11] P. Gao, V. Geissen, C. J. Ritsema, X. Mu, and F. Wang, "Impact of climate change and anthropogenic activities on stream flow and sediment discharge in the Wei River basin, China," Hydrology and Earth System Sciences, vol. 17, no. 3, pp. 961-972, 2013.

[12] G. Zhao, X. Mu, A. Strehmel, and P. Tian, “Temporal variation of streamflow, sediment load and their relationship in the Yellow River Basin, China," PLoS ONE, vol. 9, no. 3, Article ID e91048, 2014.

[13] Z. Ye, Y. Chen, and X. Zhang, "Dynamics of runoff, river sediments and climate change in the upper reaches of the Tarim River, China," Quaternary International, vol. 336, pp. 13-19, 2014.

[14] X. Mu, X. Zhang, H. Shao et al., "Dynamic changes of sediment discharge and the influencing factors in the Yellow River, China, for the recent 90 years," CLEAN-Soil, Air, Water, vol. 40, no. 3, pp. 303-309, 2012.

[15] X. X. Lu, L. S. Ran, S. Liu, T. Jiang, S. R. Zhang, and J. J. Wang, "Sediment loads response to climate change: a preliminary study of eight large Chinese rivers," International Journal of Sediment Research, vol. 28, no. 1, pp. 1-14, 2013.

[16] A. Vacca, S. Loddo, G. Ollesch et al., "Measurement of runoff and soil erosion in three areas under different land use in Sardinia (Italy)," Catena, vol. 40, no. 1, pp. 69-92, 2000.

[17] N. Fohrer, S. Haverkamp, K. Eckhardt, and H.-G. Frede, "Hydrologic response to land use changes on the catchment scale," Physics and Chemistry of the Earth, Part B: Hydrology, Oceans and Atmosphere, vol. 26, no. 7-8, pp. 577-582, 2001.

[18] W. D. Erskine, A. Mahmoudzadeh, and C. Myers, "Land use effects on sediment yields and soil loss rates in small basins of Triassic sandstone near Sydney, NSW, Australia," Catena, vol. 49, no. 4, pp. 271-287, 2002.

[19] A. Lufafa, M. M. Tenywa, M. Isabirye, M. J. G. Majaliwa, and P. L. Woomer, "Prediction of soil erosion in a Lake Victoria basin catchment using a GIS-based Universal Soil Loss model," Agricultural Systems, vol. 76, no. 3, pp. 883-894, 2003.

[20] F. H. Hao, L. Q. Chen, C. M. Liu et al., "Impact of land use change on runoff and sediment yield," Journal of Soil and Water Conservation, vol. 18, no. 3, pp. 5-8, 2004.

[21] W. Wei, L. Chen, B. Fu, Z. Huang, D. Wu, and L. Gui, “The effect of land uses and rainfall regimes on runoff and soil erosion in the semi-arid loess hilly area, China," Journal of Hydrology, vol. 335, no. 3-4, pp. 247-258, 2007.
[22] T. Homdee, K. Pongput, and S. Kanae, "Impacts of land cover changes on hydrologic responses: a case study of Chi River Basin, Thailand," Journal of Japan Society of Civil Engineers Series B1 (Hydraulic Engineering), vol. 55, pp. S31-S36, 2011.

[23] Z. H. Shi, X. D. Huang, L. Ai, N. Fang, and G. Wu, "Quantitative analysis of factors controlling sediment yield in mountainous watersheds," Geomorphology, vol. 226, pp. 193-201, 2014.

[24] W. Sun, Q. Shao, J. Liu, and J. Zhai, "Assessing the effects of land use and topography on soil erosion on the Loess Plateau in China," Catena, vol. 121, pp. 151-163, 2014.

[25] J. P. M. Syvitski, C. J. Vörösmarty, A. J. Kettner, and P. Green, "Impact of humans on the flux of terrestrial sediment to the global coastal ocean," Science, vol. 308, no. 5720, pp. 376-380, 2005.

[26] C. S. Wu, S. L. Yang, and Y.-P. Lei, "Quantifying the anthropogenic and climatic impacts on water discharge and sediment load in the Pearl River (Zhujiang), China (1954-2009)," Journal of Hydrology, vol. 452-453, pp. 190-204, 2012.

[27] C. Shi, Y. Zhou, X. Fan, and W. Shao, "A study on the annual runoff change and its relationship with water and soil conservation practices and climate change in the middle Yellow River basin," Catena, vol. 100, pp. 31-41, 2013.

[28] D. E. Walling, The Impact of Global Change on Erosion and Sediment Transport by Rivers: Current Progress and Future Challenges, UNESCO, 2009.

[29] C. Miao, L. Yang, B. Liu, Y. Gao, and S. Li, "Streamflow changes and its influencing factors in the mainstream of the Songhua River Basin, Northeast China over the past 50 years," Environmental Earth Sciences, vol. 63, no. 3, pp. 489-499, 2011.

[30] K.-H. Ahn and V. Merwade, "Quantifying the relative impact of climate and human activities on streamflow," Journal of Hydrology, vol. 515, pp. 257-266, 2014.

[31] P. Gao, X.-M. Mu, F. Wang, and R. Li, "Changes in streamflow and sediment discharge and the response to human activities in the middle reaches of the Yellow River," Hydrology and Earth System Sciences, vol. 15, no. 1, pp. 1-10, 2011.

[32] J. X. Xu, "The wind-water two-phase erosion and sedimentproducing processes in the middle Yellow River basin, China," Science in China, Series D: Earth Sciences, vol. 43, no. 2, pp. 176$186,2000$.

[33] Y. Zhang, P. Wang, B. Wu, and S. Hou, "An experimental study of fluvial processes at asymmetrical river confluences with hyperconcentrated tributary flows," Geomorphology, vol. 230, pp. 26-36, 2015.

[34] X.-Y. Liu, S.-Z. Hou, and W.-H. Chang, "Cause of main channel shrinkage occurred to the Inner-Mongolia reaches of Yellow River," Journal of Hydraulic Engineering, vol. 40, no. 9, pp. 10481054, 2009.

[35] Y. Qin, X. F. Zhang, F. L. Wang, H. Yan, and H. Han, "Scour and silting evolution and its influencing factors in Inner Mongolia reach," Acta Geographica Sinica, vol. 66, no. 3, pp. 324-330, 2011.

[36] J. X. Xu, "Erosion and sediment yield of 10 small tributaries joining Inner-Mongolia reach of upper Yellow River in relation with coupled wind-water processes and hyperconcentrated flows," Journal of Sediment Research, no. 6, pp. 28-37, 2013.

[37] T. Liu, S. F. Zhang, and S. X. Liu, "Primary analysis of the relationship between storm runoff and sediment yield in Tenwatershed-a case study in Xiliu Brook," Journal of Water Resources \& Water Engineering, vol. 18, no. 3, pp. 18-21, 2007.

[38] P. Wang, Y. Tian, S. Z. Hou, and Y.-F. Zhang, "Analysis on characteristics of flow and sediment of the hyperconcentration 
tributaries of Inner Mongolia reach of the Yellow River," Yellow River, vol. 34, no. 11, pp. 39-42, 2012.

[39] P. Wang, S. Z. Hou, Y. F. Zhang et al., "Scouring and silting characteristics of hyperconcentrated floods of ten tributaries of upper Yellow River," Journal of Sediment Research, vol. 1, pp. 6773, 2013.

[40] H. B. Mann, "Nonparametric tests against trend," Econometrica, vol. 13, no. 3, pp. 245-259, 1945.

[41] M. G. Kendall, Rank Correlation Measures, Charles Griffin, London, UK, 1975.

[42] C. Rougé, Y. Ge, and X. Cai, "Detecting gradual and abrupt changes in hydrological records," Advances in Water Resources, vol. 53, pp. 33-44, 2013.

[43] Q. Zhang, J. Li, Y. D. Chen, and X. Chen, "Observed changes of temperature extremes during 1960-2005 in China: natural or human-induced variations?" Theoretical and Applied Climatology, vol. 106, no. 3-4, pp. 417-431, 2011.

[44] A. N. Pettitt, "A non-parametric approach to the change-point problem," Journal of the Royal Statistical Society C: Applied Statistics, vol. 28, no. 2, pp. 126-135, 1979.

[45] X. Fan, C. Shi, Y. Zhou, and W. Shao, "Sediment rating curves in the Ningxia-Inner Mongolia reaches of the upper Yellow River and their implications," Quaternary International, vol. 282, pp. 152-162, 2012.

[46] J. Ding, "Statistical detection for transition point in flood time sequences," Journal of Wuhan University of Hydraulic and Electric Engineering, vol. 5, pp. 35-37, 1986.

[47] Y. Zhou, C. Shi, J. Du, and X. Fan, "Characteristics and causes of changes in annual runoff of the Wuding River in 1956-2009," Environmental Earth Sciences, vol. 69, no. 1, pp. 225-234, 2013.

[48] W. S. Wang, J. Ding, and J. L. Jin, Statistical Hydrology, China WaterPower Press, Beijing, China, 2008.

[49] H. L. Shi, C. H. Hu, Y. G. Wang et al., "Analysis on variation trends of runoff and sediment of the Yellow River Basin and reasons discussion," Yellow River, vol. 36, no. 4, pp. 1-5, 2014.

[50] W. Dong, B. Cui, Z. Liu, and K. Zhang, "Relative effects of human activities and climate change on the river runoff in an arid basin in northwest China," Hydrological Processes, vol. 28, no. 18, pp. 4854-4864, 2013.

[51] P. Gao, Streamflow and Sediment Discharge Change Trend and Its Response to Human Activities in the Middle Reaches of the Yellow River, University of Chinese Academy of Sciences (Research Centre of Soil and Water Conservation \& Eco-Environment), Yangling, China, 2010.

[52] K. Liang, C. Liu, X. Liu, and X. Song, "Impacts of climate variability and human activity on streamflow decrease in a sediment concentrated region in the Middle Yellow River," Stochastic Environmental Research and Risk Assessment, vol. 27, no. 7, pp. 1741-1749, 2013.

[53] S. Wang, Y. Yan, M. Yan, and X. Zhao, "Contributions of precipitation and human activities to the runoff change of the Huangfuchuan drainage basin: application of comparative method of the slope changing ratio of cumulative quantity," Acta Geographica Sinica, vol. 67, no. 3, pp. 388-397, 2012.

[54] X. J. Xu, "Temporal and spatial variation in erosion and sediment yield and the cause in the Ten small tributaries to the Inner Mongolia reaches of the Yellow River," Journal of Desert Research, vol. 34, no. 6, pp. 1-9, 2014.

[55] H. W. Chen, Q. S. Ren, and Y. M. Cao, "Analysis on the dam system construction and sediment reduction benefit of loess hilly and gully region in the Xiliugou basin to the Inner
Mongolia," Inner Mongolia Water Resources, no. 4, pp. 69-70, 2008.

[56] M. M. Li, B. F. Wu, C. Z. Yan et al., "Estimation of vegetation fraction in the upper basin of Miyun Reservoir by remote sensing," Resources Science, vol. 26, no. 4, pp. 153-159, 2004.

[57] M. G. Wolman and J. P. Miller, "Magnitude and frequency of forces in geomorphic processes," The Journal of Geology, vol. 68, no. 1, pp. 54-74, 1960. 

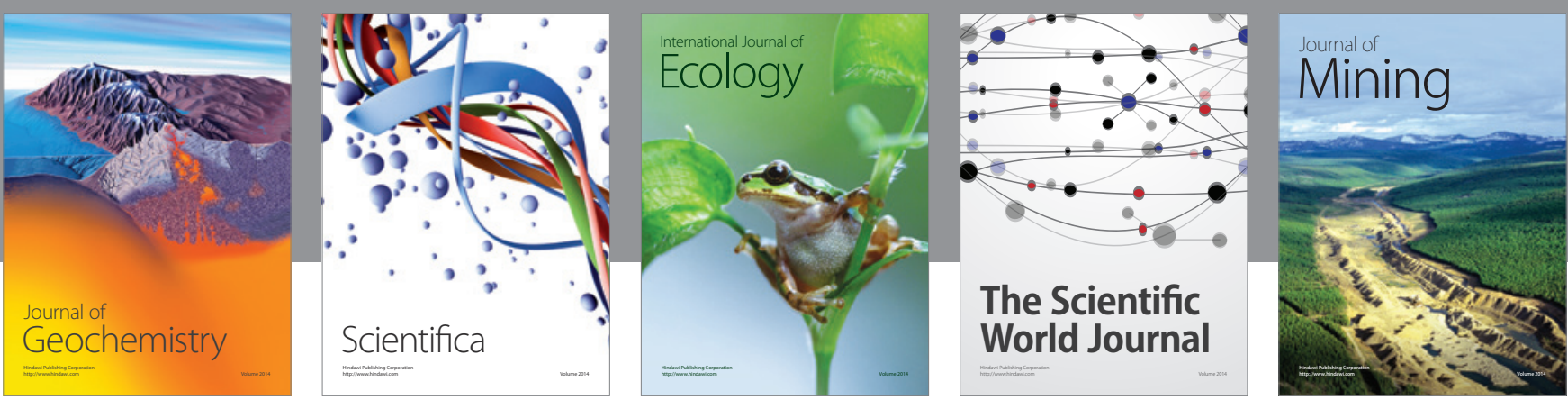

The Scientific World Journal
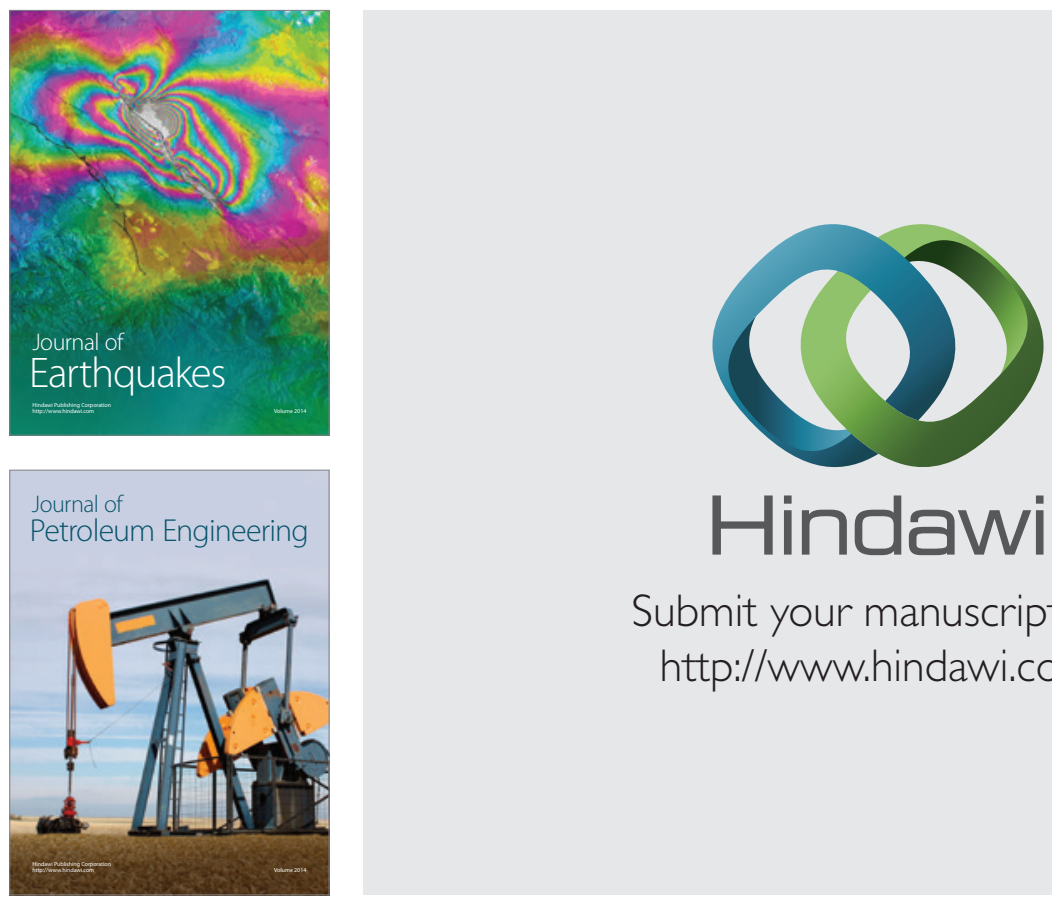

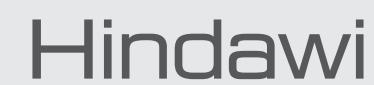

Submit your manuscripts at

http://www.hindawi.com
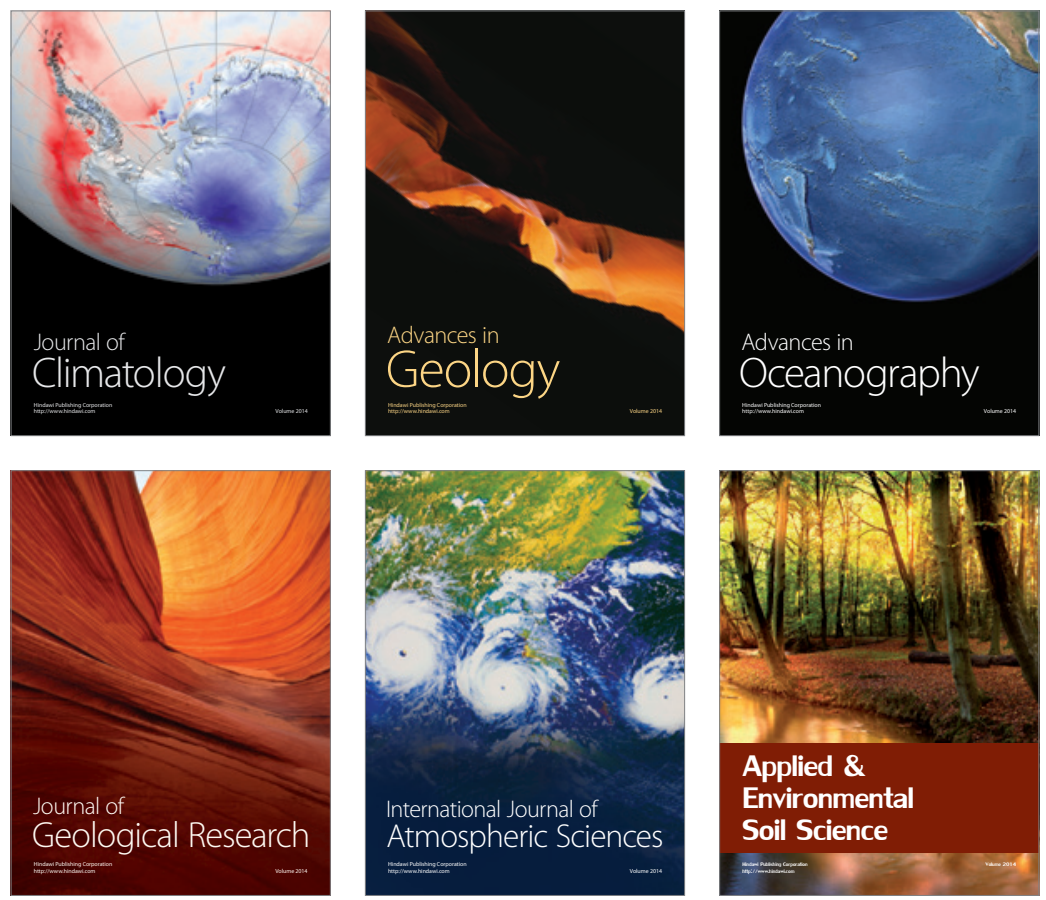
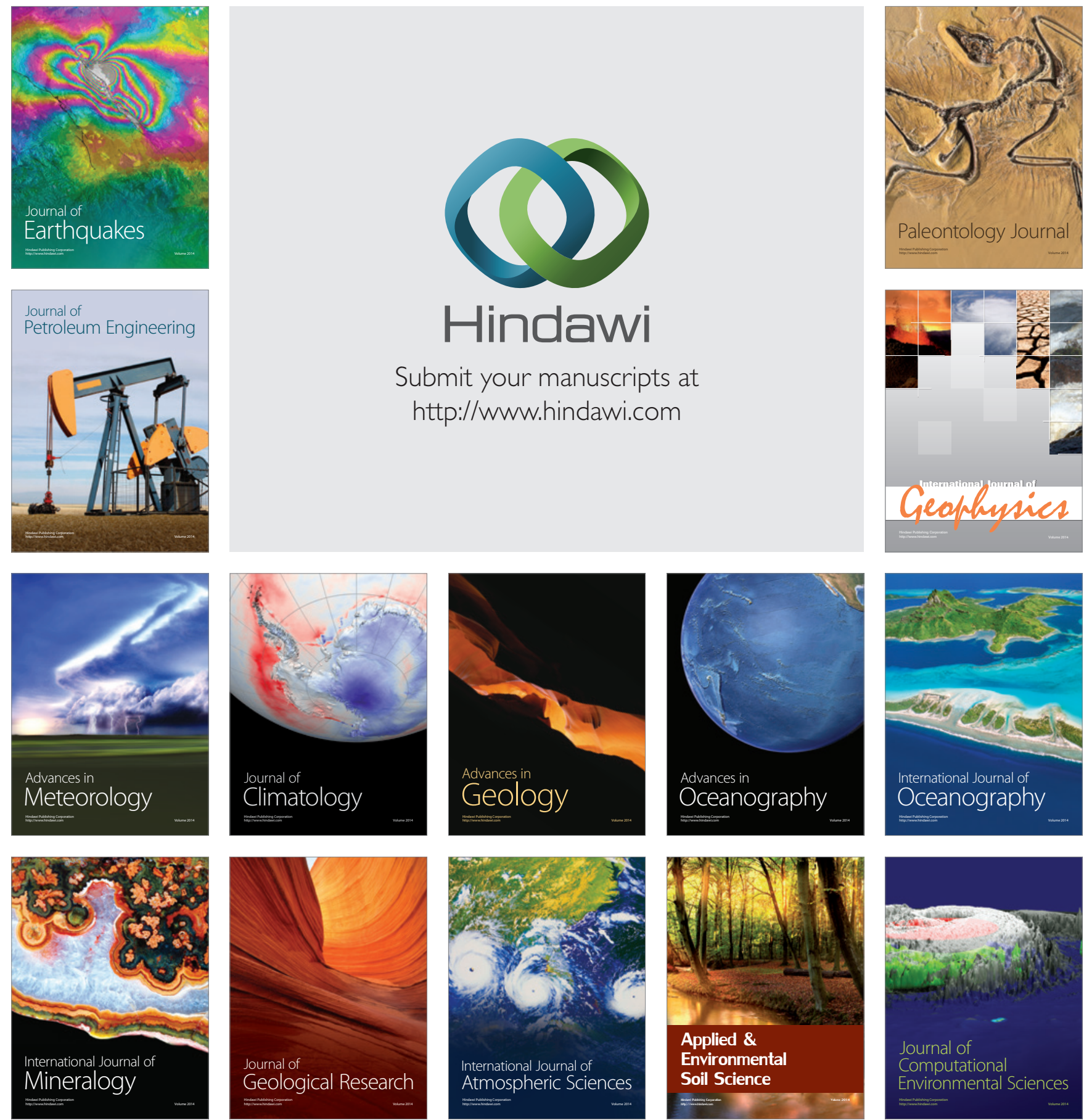